\title{
МЕТОДИКА ПРЕПОДАВАНИЯ АНГЛИЙСКОГО ЯЗЫКА ДЛЯ СТУДЕНТОВ ЮРИДИЧЕСКИХ СПЕЦИАЛЬНОСТЕЙ
}

\section{ENGLISH TEACHING METHODOLOGY FOR LAW STUDENTS}

P. Kondratev

Summary: This article reveals topical problems of methodological development and teaching English for students of legal specialties. Also presented are modern and innovative methods of teaching English for law students. The principles of the selection of teaching methods, taking into account the specifics of the initial level of knowledge of the students of the group when entering the university are outlined. The purpose of the study is to identify the main methodological approaches to teaching English for law students in domestic and foreign literature. In conclusion, the author notes that in order to achieve the maximum effect, teaching English to law students should be multidimensional, including classroom, independent and extracurricular work.

Keywords: teaching, English, student, university, lawyer, legal specialty, teacher, learning, grammar, vocabulary, communicative competence.
$\mathrm{H}$ ормативно-правовая система Российской Федерации, как правило, формируется на основании международных законодательных актов, для объективного понимания которых необходимо изучение документов на английском языке, который является международным. Кроме того, российское законодательство имеет множество спорных моментов. В контексте определенного судебного дела, изучение аналогичных ситуаций из международной и зарубежной практики может стать хорошим инструментом аргументирования виновности или невиновности фигурантов дела, а иногда сыграть и решающую роль.

В связи с этим для достижения успеха в профессиональной деятельности, студенты юридических специальностей в обязательном порядке должны знать английский язык на уровне не ниже intermediate, обладать запасом профессиональной лексики. При этом на сегодняшний день в современной педагогической теории и практике отсутствует единая комплексная методика обучения студентов юридических специальностей английскому языку, что существенно усложняет весь процесс преподавания. Кроме того, язык, в т.ч. язык юридической терминологии является живым организмом, который постоянно изменяется и дополняется. В связи с этим преподаватели ВУЗов вынуждены постоянно находиться в поиске и адаптации разработанных методик к каждому конкретному случаю - каждому конкретному набору студентов.

\author{
Кондратьев Павел Борисович \\ старший преподаватель, Санкт-Петербургский \\ юридический институт (филиал) Университета \\ прокуратуры РФ \\ pbkon@list.ru
}

Аннотация: В данной статье раскрыты актуальные проблемы методических разработок и преподавания английского языка для студентов юридических специальностей, а также современные и инновационные методики преподавания английского языка для студентов-юристов, принципы подбора методик обучения с учетом специфики изначального уровня знаний студентов группы при поступлении в ВУЗ. Цель работы заключается в выявлении основных методических подходов к преподаванию английского языка для студентов юридических ВУЗов в отечественной и зарубежной литературе. В заключении автором отмечается, что для достижения максимального эффекта преподавание английского языка для студентов юридических специальностей должно носить многоаспектный характер, в т.ч. включать в себя аудиторную, самостоятельную и внеклассную работу.

Ключевые слова: преподавание, английский язык, студент, ВУЗ, юрист, юридическая специальность, педагог, обучение, грамматика, лексика, коммуникативные компетенции.

На основании вышесказанного следует отметить, что выбранная тема исследования актуальна и целесообразна для исследования в контексте данной работы, что определило формулировку цели и задач: Цель работы заключается в выявлении основных методических подходов к преподаванию английского языка для студентов юридических ВУЗов в отечественной и зарубежной литературе. Для достижения поставленной цели в ходе работы необходимо выполнить ряд задач следующего характера:

- выявить ключевые проблемы методологии преподавания английского языка для студентов юридических специальностей;

- рассмотреть методики преподавания, наиболее часто используемые в ВУЗах России;

- рассмотреть инновационные методики преподавания, достаточно редко использующиеся отечественными педагогами;

- проанализировать традиционные и инновационные методики.

Одной из ключевых проблем обучения современных студентов профессиональному английскому языку, т.е. в контексте получения студентами высшего образования, в т.ч. юридических специальностей, является высоко дифференцированная неоднородность знаний студентов, вступающих в ВУЗы. С одной стороны, если говорить о студентах, поступающих на юридические факультеты 
отечественных ВУЗов, проживающих до этого и обучающихся на территории России, большинство из них учатся по одной и той же общеобразовательной программе (за исключением студентов гимназий, лицеев и прочих специализированных общеобразовательных учреждений с повышенными требованиями). С другой стороны, обучение в средней школе по одной общеобразовательной программе не гарантирует одинаковых результатов по факту ее завершения. Для современной системы образования России распространенной ситуацией является то, что качество преподавания в Москве и крупных городах-мегаполисах на порядок выше, чем качество обучения иностранным языкам в регионах, а тем более небольших муниципальных образований (села, деревни, ПГТ и т.д.). Как правило, даже учителя иностранного языка, работающие в средних образовательных учебных заведениях крупных городов, имеют более высокоразвитые профессиональные компетенции, чем учителя в небольших населенных пунктах.

Bсе это приводит к тому, что определенная доля студентов, поступающих в ВУЗы, в программе изучения английского языка которых заложено изучение профессиональной составляющей языка - профессиональной лексики и специфики стиля соответствующего подъязыка, не могут эффективно изучать данный блок знаний, так как не имеют сформированных компетенций общеобразовательного английского языка. Данный аспект, безусловно, должен быть учтен в разработке комплексной методики преподавания английского языка для студентов юридических специальностей, в рамках конкретного ВУЗа.

Еще одной проблемой при выработке комплексной методики преподавания английского языка является специфика юридической терминологии в рамках нормативно-правовых актов различных стран. В особенности это важно для студентов, профильным направлением обучения которых является международное право. Очень четко данный аспект отображается в различиях между терминами одного и того же семантического значения в нормативно-правовых актах США и Великобритании. Например, Например, термины «solicitor» и «barrister» существуют только в британском праве, «сounselor» (советник, адвокат) - в США и Ирландии.

Проблемы социализации являются всегда актуальными при изучении иностранного языка. Поэтому, при обучении студентов-юристов иностранному языку надо иметь в виду, что современному специалисту необходимо иметь уровень, который позволил бы ему общаться при необходимости со специалистами из других стран. Для этого он должен знать основы грамматики, но, главное, он должен знать лексику юридической направленности [6]. Среди методик преподавания английского языка для студентов юридических специальностей мож- но выделить как традиционные, так и инновационные.

К традиционным методикам обучения относятся:

- чтение статей, новостей, теоретического материала освещающих профессиональные темы юридической дисциплины;

- пересказ / рассказ изученной теоретической темы, того или иного научно-исследовательского вопроса, прочитанного в статье;

- изучение юридической профессиональной лексики;

- разбор нормативно-правовых актов на английском языке (чтение, перевод, анализ, ответы на вопросы, позволяющие понять, насколько студент понял прочитанное);

- разбор примеров судебной практики;

- прослушивание аудиозаписей диалогов на темы, подразумевающие обсуждение тех или иных юридических вопросов.

Среди нетрадиционных методик обучения можно выделить:

- просмотр документальных и художественных фильмов в аудитории или самостоятельно, выполнение после просмотра ряда заданий, позволяющих оценить, насколько студент понял события кино картины;

- организация диалоговых занятий различной формы, в ходе которых студенты разбиваются на группы и обсуждают те или иные темы юриспруденции, определенные им преподавателем или выбранные самостоятельно;

- разговорные клубы и прочие методы внеаудиторной практики разговорных навыков;

- проектная деятельность студентов [1, с. 255].

При этом следует отметить, что если большая часть группы имеет низкий уровень знаний, при подборе материалов для реализации традиционных и нетрадиционных методов обучения, рекомендуется отдавать предпочтение адаптированным материалам под усредненный уровень группы. К сожалению, в рамках преподавания английского языка в ВУЗе, большинство преподавателей не будут подбирать материалы под уровень знаний каждого отдельного студента. Однако реализовать это без существенного увеличения нагрузки на преподавателя вполне возможно посредством проведения как входных, так и периодических тестирований студентов на определение текущего уровня знаний языка и разбивки студентов на группы. В ходе реализации тех или иных методов обучения для каждой группы студентов можно подобрать учебный материал, максимально соответствующий ее общему уровню развития языка. Такой подход является наиболее эффективным.

Преподавание всего курса иностранного языка для 
студентов юридических специальностей должно вестись исключительно на английском языке. Во многих ВУЗах России, в частности ВУЗах с исключительно юридической направленностью это является существенной проблемой, так как процесс общения вне рамок учебных заданий, а так же пояснение грамматических, лексических и прочих вопросов, многие педагоги транслируют на русском.

В современной методике преподавания иностранных языков основной упор делается на формирование коммуникативной компетенции. Коммуникативную компетенцию юриста можно определить как «способность специалиста осуществлять коммуникацию в процессе выполнения различных правовых действий и решения юридических задач на основе специально сформированных знаний и умений» [2, с. 233].

В этой связи подготовка юриста в рамках курса дисциплины «Иностранный язык в сфере юриспруденции» требует обучать студентов языку специальности и формировать у них умения и навыки, необходимые для выполнения профессиональной деятельности на английском языке: умения свободно ориентироваться в текстах юридического содержания, делать сообщения, вести беседу и осуществлять письменный и устный перевод с английского языка на русский и с русского языка на английский в рамках профессиональной тематики и составлять юридические документы.

Наиболее эффективными методиками формирования и развития данных компетенций у студентов юридических факультетов являются: дебаты, круглый стол, ролевые игры.

В качестве примера можно привести игру «Эксперт Права», когда студенты приглашаются принять участие в моделируемой в аудитории телевизионной программе Legal Expert: один студент - эксперт в области российского права, второй - в области права Великобритании. Их задача отвечать на вопросы аудитории. Необходимо выбрать ведущего программы, который будет объявлять тему и представлять гостей программы (экспертов), руководить ходом обсуждения, приглашать гостей задавать интересующие их вопросы. Остальные студенты гости программы, задача которых задавать экспертам вопросы (2-3), касающиеся права России и Великобритании.

До проведения ролевой игры «Юридическая консультация» студентам предлагаются образцы иска в гражданский суд США и иска в Арбитражный Суд РФ. Студенты должны изучить и сравнить форму и структуру, найти сходство и различие этих исков. А затем проводится ролевая игра: студент А - практикующий адвокат; студент В - ведущий телепрограммы. В студию поступа- ют звонки от людей (остальные студенты группы), попавших в трудные ситуации. Задача адвоката заключается в том, чтобы помочь позвонившему решить проблему, в частности, дать рекомендации по составлению иска. Используя образцы исков, позвонившие составляют исковые заявления [3, с. 368].

Представленные методики формирования у студентов коммуникативных компетенций изучения английского языка могут осуществляться, как в виде учебной деятельности (в ходе аудиторных занятий), так и в виде внеклассных мероприятий.

Кроме того, к эффективным и инновационным методикам развития коммуникативных компетенций на английском языке, в рамках отечественной системы высшего образования и обучения студентов английскому языку в контексте данной системы, являются внеклассные методики обучения:

\section{Speaking club.}

В данном случае подразумевается организация внеклассного Speaking club с целью обсуждения новостей по различным нормативно-правовым вопросам отечественного и зарубежного законодательства, обсуждение различных коллизионных вопросов по конкретным делам судебной практики, текущих проблем действующего законодательства в различных областях юридической дисциплины и прочее.

Speaking club может быть организован, как преподавателем, так и самими студентами. Для быстрого развития языковых навыков членов клуба, рекомендуется проводить собрания 1 - 3 раза в неделю.

Для мотивации студентов к посещению клуба, преподаватель может выделить из общей оценки за прохождение курса профессионального английского языка, определенного количества баллов, которые студент сможет получить при регулярном участии в клубной деятельности.

\section{2. Обшение с иностранными студентами юриАических ВУЗов.}

Online общение на форумах, посредством Skype, Telegram, Whatsup и других приложений позволяет коммуницировать со студентами зарубежных юридических факультетов и юридических ВУЗов. Студент может, как просто периодически принимать участие в обсуждениях на интересующую его тематику на правовых форумах, так и найти товарища, среди студентов зарубежных ВУЗов на университетских форумах, для регулярного общения. Используя данный метод развития коммуникативных компетенций, студент может общаться, как в 
формате письменных сообщений, тренируя при этом навыки письма и увеличивая знания грамматики, а так же в формате аудио-сообщений или общения в видео-чате, тренируя при этом навыки аудирования и говорения. В любом из данных случаев студент будет развивать не только коммуникативные компетенции, но и увеличивать свой словарный запас.

Данную методику можно применить в форме практического проекта с презентацией его результатов на определенную дату. Это мотивирует студентов воспользоваться представленной методикой и не игнорировать рекомендации преподавателя. В случае применения данной методики в виде проектной деятельности студента, минимальным сроком проекта рекомендуется установить 3 месяца.

Презентация результатов подобного проекта может быть организована в виде одной из следующих форм:

1) устный рассказ студента на 5 - 7 минут, который может иметь следующую структуру:

- кто был субъектом проектной деятельности (студент какого ВУЗА);

- на каких площадках или с помощью каких инструментов осуществлял общение;

- какие темы и вопросы он обсуждал в ходе проекта;

- каких взглядов придерживаются зарубежные студенты по тому или иному вопросу (последнее объективно только в рамках группового общения студента с иностранными студентами, в противном случае он может только вкратце рассказать точку зрения именно своего собеседника);

- согласен ли со взглядами своего собеседника или собеседников по обсуждаемым вопросам, если нет, то почему.
Данный рассказ может подкрепляться презентацией со скриншотами из переписки студента или же короткими видео, подтверждающими фактическое общение с иностранным студентом;

2) Видео-отзыв на общение со студентом, записанный от лица иностранного студента, характеризующий коммуникативные компетенции студента, а так же краткую справку об обсужденных вопросах касательно юридической дисциплины, справку о совпадении или не совпадении точек зрения студентов по большинству вопросов;

3) Видео-созвон студента с иностранным студентом в ходе презентационного занятия, с трансляцией «созвона» через проектор. В ходе «созвона» рекомендуется презентовать краткое подведение итогов общения студентов в ходе разговора при педагоге, а также, как и в предыдущих случаях огласить тезисно обсужденные вопросы и совпадение / несовпадение точек зрения по ним [ 5, с. 165]. Последний вариант является наиболее интересным, а так же объективным для оценки результатов проектной деятельности студента, но в реалиях отечественного образования и технического обеспечения большинства ВУЗов, тяжело реализуемым.

Таким образом, все представленные внеклассные методы развития коммуникативных компетенций студентов нацелены на разговорную практику профессионального английского языка, а параллельно, на развитие знаний грамматики, увеличение лексического запаса. Для достижения максимального эффекта преподавание английского языка для студентов юридических специальностей должно носить многоаспектный характер. Комплексная методика преподавания должна включать максимально возможное количество методов аудиторной, самостоятельной и внеклассной работы.

\section{ЛИТЕРАТУРА}

1. Азизова С.М. Особенности профессионально-ориентированного обучения английскому языку студентов юридического профиля // Педагогический журнал. - 2016. - № 4. - С. 251 - 260.

2. Дворцевая А.В. Профессиональный английский язык для студентов юридических специальностей // Вестник Луганской академии внутренних дел им. Э.А. Дидоренко. - 2018. - № 1 (4). - С. $232-240$.

3. Камшукова Л.С. К вопросу о формировании иноязычной компетенции студентов-юристов // Наука и образование: новое время. - 2017. - № 6 (23). C. $365-371$.

4. Левитан К.М. Метапредметный подход в развитии инновационной профессиональной языковой личности студентов юридического ВУЗа // Язык и культура. - 2019. - № 47. - С. 217 - 230.

5. Токтоназарова К.А., Султанова Г.К. Особенности профессионально-ориентированного обучения английсому языку студентов юридического профиля // Вестник Кыргызского государственного университета им. и. Арабаева. - 2020. - № 2. - С. 163 - 167.

6. Нурхамитов М.Р., Геркина Н.В. Особенности преподавания английского языка для студентов юристов в университете. - 2017. - № 58-1. - [Электронный ресурс]. - Режим доступа: https://novainfo.ru/article/10275 (дата обращения 22.12.2020). 